\title{
O LUGAR E O HOMEM - RETROSPECTIVA 2OOI A 2006
}

\author{
Roberto Righi
}

Da esquerda para a direita, Issao Minami, curador; Roberto Righi,

I84 o autor da mostra; Caciporé Torres, escultor;

Takashi Fukushima, pintor

Crédito: Foto de Issao Minami

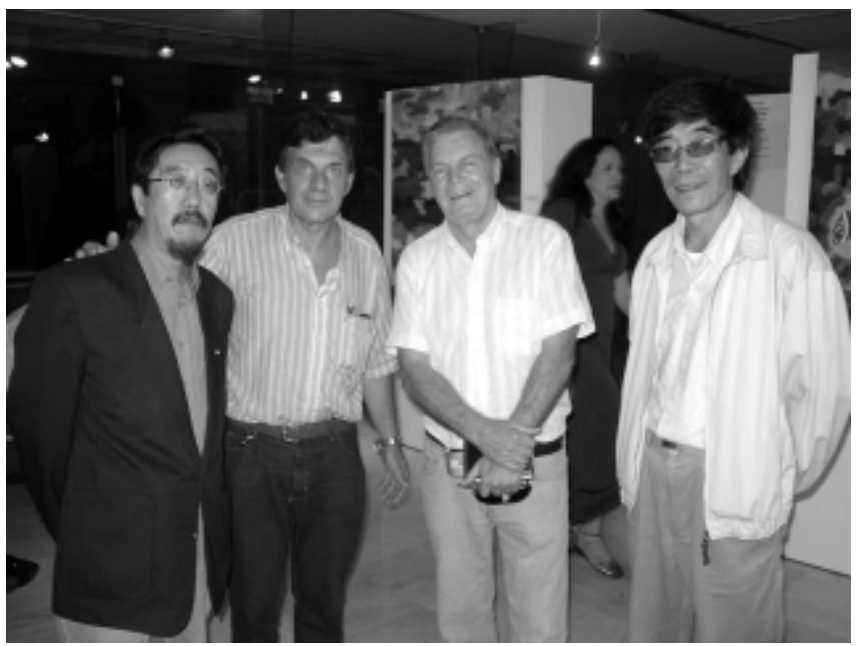

A exposição de acrílicas sobre tela do Prof. Dr. Roberto Righi aconteceu no Espaço Cultural João Calvino em 2007, sob a curadoria do Prof. Dr. Issao Minami, da FAUUSP. Essa exposição mostra uma seleção de 23 trabalhos realizados entre 1999 e 2006, que integraram três individuais e diversas coletivas no período.

A primeira individual enfocada foi "Violência e não-lugar", de caráter itinerante, com início em São Paulo, 2000, no Salão do Museu da FAUUSP e no Espaço Cultural Dado-Bier. Na seqüência, em 2001, ela foi apresentada em Santa Catarina, na Universidade Regional de Blumenau - FURB, e no Museu de Arte de Joinville - MAJ. A exposição envolveu as inter-relações entre a violência, o homem e o lugar. Refletia como as novas formas de apropriação do espaço mudam e fragilizam a permanência e conexão do homem com seu lugar e levam à violência. O alerta foi feito em uma linguagem capaz de sensibilizar e fazer refletir o cidadão comum. Issao Minami comentou, em 2002, sobre o evento: “(...) Esta exposição traduzia basicamente uma linguagem figurativa e realista e que tendia em seu final para uma abstração de origem fortemente expressionista. Hoje sua preocupação alinha-se com o tema da abstração, gerada e nascida do trabalho figurativo."

Issao Minami foi curador da segunda individual referida, realizada em 2002, no Salão Caramelo da FAUUSP, sob o tema Heranças e Identidades, e contou com a parceria do arquiteto e artista Mário Augusto Boccara, que mostrou seus relevos. Minami novamente se expressou na ocasião: "Boccara e Righi, dois do fazerurbano, artistas que sintetizam exercícios de estudo, reflexão e interpretação, buscando o encontro das heranças e identidades formais e cromáticas da arte figurativa, em sua poética marcada pelos ritmos, contrastes, filigramas, simetrias, modulações e ruídos. Enfim, mestre e aluno, trazendo instigações, contrapondo 
estilos nascentes, tendências, coadjuvantes, duplicidades com cumplicidades em diálogo singular e inusitado. Augusto Mário Boccara, do concretismo, ao perceptismo e à arte cinética, faz jus à reflexão título da exposição. (...) É possível para Righi que a arte possa traduzir em última instância a imagem do artista, a sua identidade, numa luta pelo auto-conhecimento, que tenta transgredir a derrota existencialista inexorável, da inexistência de um sentido para a vida."

A terceira individual abordada é a "Mondo acqua", realizada em 2006, na biblioteca pe. Elemar Scheid, do Centro Universitário de Jaraguá do Sul, SC. Essa exposição marcou o retorno artístico de Righi a Santa Catarina. A mostra "Violência e não-lugar", de 2001, havia sido bem recebida pela comunidade regional. Nessa outra, ele afirmou que depois de cinco anos era possível fazer uma lamentável afirmação em relação àquele tema: vive-se em um mundo no qual há ainda maior confronto social e as mudanças ocorrem em direção indesejada. A existência está sendo profundamente modificada. A felicidade real deixou de ser o referencial para a vida. Superficialmente, parece que tudo está sendo programado e codificado em uma civilização mecânica e eletrônica. Porém, mais grave é que, além daquela destruição da expressão mais humana, ocorre o recrudescimento dos valores mais negativos, como: a violência gratuita, o materialismo vazio e a barbárie social. Nessa sociedade transtornada há necessidade crescente de o artista tomar uma atitude consciente de denúncia, representada por valores éticos e estéticos a inter-relacionarem-se de forma construtiva com a sociedade. $\mathrm{O}$ artista deve posicionar-se diante dessas dramáticas contradições, superando a cômoda alienação. Essa atitude deve responder à sensação de desesperança e à depressão. A arte deve triunfar sobre um mundo corrompido, fundamental para realizar o papel da arte e do homem. Para tanto, nessa exposição, Righi muda radicalmente, criando uma frente de expressão formal e conceitual, de caráter mais poético e plástico, em reflexão acerca do mar.

Essa retrospectiva aborda também a participação em coletivas com premiações, como a menção honrosa na 28a Exposição Bunkyo e o Prêmio Estímulo na 1aㅗ Exposição de Arte Figurativa Contemporânea da Sociedade de Cultura Japonesa; também as presenças em: Carta do Descobrimento, na FunarteSão Paulo, em 1999; na Oriente Ocidente Traços de União no Brasil 500 Anos e na 29a Exposição Bunkyo, em 2002; em Artistas Arquitetos-Arquitetos Artistas, da Galeria Slaviero \& Guedes, em 2003; e na Gesto de Arte, em 2004 e 2006. Também, no período, destaca a posição de membro convidado do júri do 54응 Salão Paulista de Belas Artes, em 2003, com a crítica de arte Radha Abramo.

Concluindo, o sentido desse evento é trazer à comunidade o resultado de um trabalho de reflexão intelectual e expressão plástica. O catálogo eletrônico da exposição pode ser solicitado a robrighi@mackenzie.com.br.

\section{Roberto Righi}

Professor da Faculdade de Arquitetura e Urbanismo da Universidade Presbiteriana Mackenzie, assim como da FAUUSP, nos cursos de graduação e pós-graduação. e-mail: robrighi@mackenzie.com.br 